\title{
Impact of Blue and Red Light on Wheat Leaves
}

\section{Azizov Ibrahim Vahab, Gasymova Fazile Imtu, Ibrahimova Ulker Faik, Tagiyeva Kenul Rafik, Abdullayeva Asmar Bahruz}

Department of Photochemistry of Chloroplasts, Institute of Biology and Biotechnology, Baku, Azerbaijan

\section{Email address:}

Ibrahim.azizov47@gmail.com (A. I. Vahab)

\section{To cite this article:}

Azizov Ibrahim Vahab, Gasymova Fazile Imtu, Ibrahimova Ulker Faik, Tagiyeva Kenul Rafik, Abdullayeva Asmar Bahruz. Impact of Blue and Red Light on Wheat Leaves. Advances in Applied Physiology. Vol. 5, No. 1, 2020, pp. 6-8. doi: 10.11648/j.aap.20200501.12

Received: April 20, 2020; Accepted: May 5, 2020; Published: May 19, 2020

\begin{abstract}
The effect of blue and red light on the activity of catalase and ascorbate peroxidase, the content of proteins and soluble carbohydrates in the leaves of wheat varieties under the action of sodium chloride was investigated. The objects of the research were bread wheat Saratovskaya-29 (Triticum aestivum L.) and durum wheat Barakatli-95 (Triticum durum Desf.). Plants were grown in laboratory conditions in an aqueous medium using a Knoop nutrient medium. Experimental plants were coated with transparent films transmitting light at wavelengths of 420-480 nm (blue light) and 640-680 nm (red light). During the growing season, samples of fully formed leaves were taken for physiological and biochemical studies every week at 11 a. $\mathrm{m}$. Under the action of sodium chloride, the accumulation of hydrogen peroxide in white light was higher than in blue and red light. Low catalase activity also observed in blue and red light under the action of sodium chloride in both varieties. In the bread wheat variety Saratovskaya -29 the level of hydrogen peroxide, the activity of catalase and ascorbate peroxidase enzymes were lower than those of the Barakatli-95 durum wheat variety. Blue light stimulated the synthesis of proteins, while red light stimulated the synthesis of carbohydrates. Blue and red light prevented the formation of $\mathrm{H}_{2} \mathrm{O}_{2}$ under the action of $\mathrm{NaCl}$.
\end{abstract}

Keywords: Blue Light, Red Light, Catalase, Ascorbate Peroxidase, Proteins, Carbohydrates

\section{Introduction}

Some of the essential factors necessary for the growth, development, and productivity of plants are the intensity and spectral composition of light. Under the conditions of insufficient provision of sunlight, the process of photosynthesis is disrupted, growth, development, yield, and plant resistance reduced. There are numerous works in the literature on the study of the intensity and spectral composition of light on growth and development, photosynthesis, and plant productivity $[1,3,8,9,10-12,13$, 16]. Light also acts as an effective regulator that controls the morphogenesis of plants during the individual development of plants [15]. The spectral composition of light affects the growth and development of wheat seedlings. Under optimal growing conditions in red light, there is a tendency to stimulate the growth of both the aerial part and the roots, compared with seedlings grown in white and blue light. More carbohydrates synthesized in the leaves under red light than under blue light and, on the contrary, more proteins synthesized under blue light than under red light [3-7].

The study of the effect of red light on the synthesis of proteins and carbohydrates in plant leaves is of both theoretical and practical value. Our research aimed to study physiological and biochemical characteristics of wheat genotypes under the influence of blue and red light.

\section{Material and Methods}

Two varieties of winter wheat Saratovskaya-29 (Triticum aestivum L.) and Barakatli-95 (Triticum durum Desf.) were used in the study. Plants were grown in laboratory conditions in an aqueous medium using a Knoop nutrient medium. Sodium chloride at a concentration of $100 \mathrm{mmol}$ was added to the experimental plants.

Experimental plants were coated with transparent films transmitting light at wavelengths of 420-480 nm (blue light) and 640-680 $\mathrm{nm}$ (red light). During the growing season, samples of fully formed leaves were taken for physiological and biochemical studies every week at $11 \mathrm{a}$. $\mathrm{m}$. Photosynthetic pigments were determined by homogenizing 
the leaves in $96 \%$ ethanol, with further centrifugation at 200 g. Measurements were performed on a spectrophotometer at wavelengths of 665,649 , and $440.5 \mathrm{~nm}$, using the coefficient of Wintermans, De Mots, 1965 [2]. The content of soluble sugars was determined by the accelerated bichromate method, at a wavelength of $630-570 \mathrm{~nm}$ [2]. The protein content was determined on a SP 2000 spectrophotometer at a wavelength of 230 and $260 \mathrm{~nm}$, according to the method of Kalb, Bernlohr [2]. The determination of hydrogen peroxide was carried out using a method based on the formation of a colored compound - a titanium peroxide complex [14]. The concentration of $\mathrm{H}_{2} \mathrm{O}_{2}$ was calculated from the standard calibration curve of the level of hydrogen peroxide and expressed in mmol / $\mathrm{g}$ fresh weight. Catalase activity (CAT) was measured by the rate of $\mathrm{H}_{2} \mathrm{O}_{2}$ degradation according to the procedure [14]. A drop in optical density was recorded for 1 minute after adding a solution of $100 \mu \mathrm{l}$ of $0.1 \mathrm{M} \mathrm{H}_{2} \mathrm{O}_{2}$ to the enzyme extract and the enzyme activity was expressed in mmol of decomposed peroxide / $\mathrm{g}$ fresh weight per minute. The activity of ascorbate peroxidase (APO) was determined at $\mathrm{pH} 7.0$ by the decrease in light absorption at $290 \mathrm{~nm}$. The protein content was analyzed according to the Bradford method, using BSA as a standard [2].

The experiments were performed in triplicate biological repetition and each reproduced independently 2-3 times. The figures and tables show the average values and their standard deviations $(\mathrm{M} \pm \sigma)$. The significance of differences between the options was evaluated using t-student test.

\section{Results and Discussion}

The influence of blue and red light on physiological and biochemical parameters was unidirectional, but there were varietal differences. In blue light, plants grew more intensely than in red light. Under the action of sodium chloride, the accumulation of hydrogen peroxide in white light was higher than in blue and red light (table 1). Low catalase activity was also observed in blue and red light under the action of sodium chloride in both varieties. In bread wheat variety Saratovskaya -29 level of hydrogen peroxide, the activity of catalase and ascorbate peroxidase enzymes were lower than that of the Barakatli-95 durum wheat variety. The accumulation of carbohydrates and proteins was different: red light contributed to the synthesis of carbohydrates, and blue light contributed to the synthesis of proteins. The rapid growth of plants and the low content of hydrogen peroxide under the action of salt in blue light can explained by the effect of blue light on the metabolic processes of the cell.

Table 1. The effect of blue and red light on the physiological and biochemical parameters of wheat leaves*

\begin{tabular}{|c|c|c|c|c|c|c|}
\hline Wheat variety & Light spectrum & $\mathrm{H}_{2} \mathrm{O}_{2}, \mathrm{mkmol} / \mathrm{g}$ & Carbohydrates mg / g & $\begin{array}{l}\mathrm{CAT}, \mu \mathrm{mol} / \mathrm{mg} \\
\text { protein }\end{array}$ & $\begin{array}{l}\text { APO, } \mu \mathrm{mol} / \mathrm{mg} \\
\text { protein }\end{array}$ & $\begin{array}{l}\text { Protein, mkg } \\
/ \mathrm{ml}\end{array}$ \\
\hline \multirow{3}{*}{$\begin{array}{l}\text { Saratovskaya-29 } \\
\text { Control }\end{array}$} & White & $1,1 \pm 0,08$ & $40 \pm 2,3$ & $0,6 \pm 0,02$ & $1,0 \pm 0,08$ & $41 \pm 2,2$ \\
\hline & Red & $0,9 \pm 0,07$ & $34 \pm 1,5$ & $0,5 \pm 0,01$ & $1,3 \pm 0,09$ & $37 \pm 1,4$ \\
\hline & Blue & $1,6 \pm 0,09$ & $30 \pm 1,3$ & $0,4 \pm 0,03$ & $0,2 \pm 0,07$ & $43 \pm 2,3$ \\
\hline \multirow{3}{*}{$\begin{array}{l}\text { Saratovskaya-29 } \\
100 \mathrm{mmol} \mathrm{NaCl}\end{array}$} & White & $2,8 \pm 0,09$ & $50 \pm 2.2$ & $1,8 \pm 0,09$ & $8,1 \pm 0,09$ & $46 \pm 2,2$ \\
\hline & Red & $1,9 \pm 0,06$ & $60 \pm 3,4$ & $0,7 \pm 0,05$ & $2,2 \pm 0,07$ & $42 \pm 1,5$ \\
\hline & Blue & $1,6 \pm 0,05$ & $40 \pm 4,5$ & $0,6 \pm 0,04$ & $1,3 \pm 0,04$ & $52 \pm 3,3$ \\
\hline \multirow{3}{*}{$\begin{array}{l}\text { Barakatli } 95 \\
\text { Control }\end{array}$} & White & $1,8 \pm 0,07$ & $32 \pm 5,1$ & $1,8 \pm 0,07$ & $0,6 \pm 0,03$ & $100 \pm 3,6$ \\
\hline & Red & $0,9 \pm 0,04$ & $30 \pm 2,4$ & $1,0 \pm 0,06$ & $0,8 \pm 0,02$ & $95 \pm 1,5$ \\
\hline & Blue & $1,7 \pm 0,05$ & $24 \pm 3,3$ & $1,7 \pm 0,08$ & $0,5 \pm 0,06$ & $100 \pm 2,7$ \\
\hline \multirow{3}{*}{$\begin{array}{l}\text { Barakatli } 95 \\
100 \mathrm{mmol} \mathrm{NaCl}\end{array}$} & White & $3,4 \pm 0,04$ & $60 \pm 2,6$ & $2,2 \pm 0,04$ & $0,6 \pm 0,5$ & $108 \pm 3,5$ \\
\hline & Red & $2,9 \pm 0,09$ & $65 \pm 1,7$ & $2,2 \pm 0,09$ & $0,8 \pm 0,07$ & $100 \pm 2,4$ \\
\hline & Blue & $3,0 \pm 0,06$ & $50 \pm 2,8$ & $1,8 \pm 0,08$ & $0,5 \pm 0,04$ & $110 \pm 1,5$ \\
\hline
\end{tabular}

*Each value represents the mean $\pm \mathrm{SD}$ (standard deviation) for the mean $\mathrm{n}=3$ independent experiments $\mathrm{p}=0.05$.

There is evidence that during drought and salinization, blue light contributes to the synthesis of low molecular weight compounds that increase the water retention capacity of the cell $[17,18]$. In this work, it was also shown that under the salinization condition, the seedling growth rate decreased by $20 \%$ in blue light, while in red light, it fell by $50 \%$.

Many authors have noted the regulatory effect of blue light on plant metabolism through cryptochromes. Blue light photoreceptors are flavins and carotenoids. The yellow pigment riboflavin, a receptor of blue, is the near-ultraviolet light called cryptochrome. It is present in all plants. In the ultraviolet part of the spectrum (320-390 nm), another receptor system is probably working, including pyrazinepyrimidine derivatives or pterins. Receptors undergo redox transformations, quickly transferring electrons to other acceptors. Plant phototropism was determined by the receptor complex of the stem apex, which includes cryptochrome and carotenoids. Blue light receptors found in the cells of all tissues, are localized in the plasmalemma and other membranes. The photomorphogenic effect of red light on a plant carried out through phytochromes F660 and F730.

\section{Conclusions}

1. Blue and red light prevent the formation of hydrogen peroxide in wheat cells under the action of sodium chloride.

2. Blue light stimulates the synthesis of proteins, and red light stimulates the synthesis of carbohydrates in wheat cells.

This work was supported by Azerbaijan National Academy of Sciences under the Azerbaijan-Belarus project: "Phytochrome regulation of photochemical processes as a factor in increasing the stress tolerance of cultivated plants." 


\section{References}

[1] Bell L. H. 1972. The quality of light as a factor regulating the energy of photosynthesis. In: Theoretical foundations of photosynthetic productivity. -M.: Science, pp. 50-62. (in Russian).

[2] Large workshop "Biochemistry". 2012. P. 108 P. (in Russian).

[3] Bradford, M. M. (1976). Rapid and Sensitive Method for the Quantitation of Microgram Quantities of Protein Utilizing the Principle of Protein-Dye Binding. Anal. Biochem. 72: 248254.

[4] Voskresenskaya N. P. 1965. Photosynthesis and spectral composition of light. -M.: Nauka, 312 p. (in Russian).

[5] Voskresenskaya N. P., Nechaeva V. P. 1967. The effect of blue, red and green light on the content of protein, nucleic acids, and chlorophyll in young barley plants. Plant physiol. No. 2. Issue. 14. pp. 299-307.0 (in Russian).

[6] Voskresenskaya N. P., Nechaeva E. P., Vlasova M. P., Nichiporovich A. A. 1968. The value of blue light and kinetin for the restoration of the photosynthetic apparatus of aging barley leaves. Plant physiol. Vol. 15, no. 5, pp. 890-897. (in Russian).

[7] Voskresenskaya N. P., Omarova I. S., Krylov Yu. V. 1968. The effect of long and short-term effects of blue light on the photosynthesis of pea plants. DAN SSSR. V. 182, No. 6. pp. 1443-1449. (in Russian).

[8] Voskresenskaya N. P. 1976. The regulatory role of blue light in the formation of photosynthetic apparatus activity. Physiol. and biochemistry of cultivated plants. Vol. 8, no. 4. pp. 339348. (in Russian).

[9] Gold V. M., Gaevsky N. A., Botkina T. I., Grigoryev Yu. S. 1973. The activity of photochemical reactions in aspidistra in blue and red light. Plant physiol. V. 20, No. 3. pp. 539-543. (in Russian).

[10] Karnachuk R. A. 1987. Regulatory effect of green light on the growth and photosynthesis of leaves. Plant physiol. V. 34. № 3. pp. 765-773. (in Russian).

[11] Karnachuk R. A., Golovatskaya I. F. 1998. Hormonal status, growth, and photosynthesis of plants grown in the light of various spectral compositions. Plant physiol. T. 45, No. 6. pp. 925-934. ( in Russian).

[12] Krasnovsky A. A. 1975. Plant cell photoreceptors and paths of light regulation. Photoregulation of metabolism and plant morphogenesis. M: Science. pp. 5-15. (in Russian).

[13] Kuznetsov E. D., Ivanova Z. P., Shakhov A. A. 1978. Phytochrome-dependent photoregulation, its mechanisms and significance for light control of plants. Problems of plant phyto-energetics. Alma-Ata, Issue. 5. pp. 21- 42. (in Russian).

[14] Kumar G, Knowles N. R. 1993. Changes in Lipid Peroxidation and Lipolytic and Free-Radical Scavenging Enzyme Activities during Aging and Sprouting of Potato (Solanum tuberosum) Seed-Tubers. Plant Physiol. 102 (1): 115-124.

[15] Petrov V. E., Loseva N. L. 1986. Energy of an assimilating cell and photosynthesis. Energy aspects of plant resistance. Kazan: Kazan Publishing House, University, pp. 5-76. (in Russian).

[16] Tertyshnaya Yu. V., Levina N. S. 2016. The influence of the spectral composition of light on the development of crops. Agricultural machinery and technology DOI 10.22314.20737599. N5. pp. 24-29. (in Russian).

[17] Chayka M. T., Savchenko G. E. 1981. Chlorophyll biosynthesis during the development of plastids. Minsk: Science and Technology, 1981.168 p. (in Russian).

[18] Yakushenkova, T. P. 2002. Comparative effect of blue and red light on some physiological parameters and resistance of spring wheat seedlings. Author. Diss. 21p. in Russian). 